\title{
Prevalence and Antibiogram of Methicillin Sensitive and Methicillin Resistant Staphylococcus aureus Isolated from Pus Samples in a Tertiary Care Teaching Hospital
}

\author{
Sowmya Govindanahalli Shivappa, Raghavendra Rao Morubagal*, Rashmi \\ Padmanabha Mahale and Ranjitha Shankare Gowda
}

Department of Microbiology, JSS Medical College, JSS Academy of Higher Education and Research, Mysore 570 015, Karnataka, India.

\begin{abstract}
Staphylococcus aureus is an important pathogen causing bacterial infection of skin lesions, such as burns, traumatic lesions, diabetic ulcers and post operative infections. The most common organism isolated from wound infections in our hospital is Staphylococcus and there have been several reports of MRSA isolates from pus samples during previous years. The aim of the present work is to study the rate of Staphylococcal wound infection and also to know the Antibiogram of Methicillin Sensitive and Methicillin Resistant Staphylococcus aureus. Staphylococcus aureus isolated from pus samples were identified based on colony morphology, Gram stain, Catalase and Coagulase test. Antibiotic susceptibility testing by disc diffusion was performed by Kirby Bauer method as per CLSI guidelines. Out of 595 samples collected, 534 [89.7\%] yielded growth of one or more bacterial species. Among 534 culture positive samples, 152 yielded pure growth of only staphylococcal species. $40.3 \%$ of the wound infections were caused by Staphylococcus species and among them $81.7 \%$ were caused by Staphylococcus aureus. The overall rate of MRSA infection in the present study was $29.6 \%$. Significant difference was observed in the susceptibility pattern of Methicillin Sensitive and Methicillin Resistant Staphylococcus aureus. MRSA continues to be a major threat in the health care setting. The increased level resistance pattern of Methicillin Resistant Staphylococcus aureus observed in our study may be due to the fact that ours is a tertiary care hospital with extensive usage of broad spectrum antibiotics leading to survival advantage and persistence of drug resistant pathogens.
\end{abstract}

Keywords: Staphylococcus aureus, MRSA, MSSA, Wound infections, Antibiotic Susceptibility pattern.

*Correspondence: getdrraghurao@yahoo.com; +91-9902555558.

(Received: 26 October 2018; accepted: 18 December 2018)

Citation: Sowmya Govindanahalli Shivappa, Raghavendra Rao Morubagal, Rashmi Padmanabha Mahale and Ranjitha Shankare Gowda, Prevalence and Antibiogram of Methicillin Sensitive and Methicillin Resistant Staphylococcus aureus Isolated from Pus Samples in a Tertiary Care Teaching Hospital, J Pure Appl Microbiol., 2018; 12(4):2297-2303. http://dx.doi.org/10.22207/ JPAM.12.4.71

(c) The Author(s) 2018. Open Access. This article is distributed under the terms of the Creative Commons Attribution 4.0 International License which permits unrestricted use, sharing, distribution, and reproduction in any medium, provided you give appropriate credit to the original author(s) and the source, provide a link to the Creative Commons license, and indicate if changes were made. 


\section{INTRODUCTION}

Staphylococci are an important pathogen causing human disease. It has an exceptional ability to colonise, spread and cause outbreaks in hospitals. They can be cultured even from dried clinical samples after several months, and are very hardy bacteria. ${ }^{1}$ Therefore, it is not surprising that even in spite of availability of effective antimicrobial agents, improved health care conditions and stringent hospital infection control measures, Staphylococcus aureus has established itself as a major human pathogen.

Staphylococcus aureus is a major pathogen causing secondary bacterial infection complicating pre-existing skin lesions, such as burns, traumatic lesions, diabetic ulcers, osteomyelitis and surgical site infections. Staphylococcus isolated in hospitals has shown an alarming tendency to develop resistance to antimicrobial drugs $^{2}$ and has been recognized as one of the important challenges in control of hospital infections.

Resistance to penicillin appeared in 1942. The emergence of infections due to Methicillin Resistant Staphylococcus aureus [MRSA] during late 1970 s and 1980 s world over ${ }^{3}$ and their introduction and spread in hospitals increased the rate of hospital acquired infections in the hospitals. The emerging threat of vancomycin resistance among coagulase negative Staphylococcus and Enterococci poses a serious public health concern as vancomycin has been the drug of choice for treatment of resistant gram positive organisms.

Wound infections are the most common type of pyogenic infections that contributes for prolonged hospital stays, significantly increasing the cost of medical care and also have an important role in the development of multi drug resistance. Staphylococcus is the most common organism causing wound infections and isolated from pus samples in our hospital and, there have been several reports of MRSA isolates from pus samples during previous years. Thus a study was taken up to detect the number of wound infections due to Staphylococci and also to study their susceptibility pattern which helps in better management of the infection. The main aim of the present study was to find out the rate of Staphylococcal wound infection and also to know the Antibiotic susceptibility pattern of Methicillin
Sensitive and Methicillin Resistant Staphylococcus aureus isolated from pus samples.

\section{Methodology}

All patients admitted and/or attending surgery and orthopedics OPD with suspected microbial wound infection and the discharge, which yielded growth of staphylococci, were included in the present study.

\section{Sample collection}

Pus from the wound was collected using two sterile swabs after cleaning the wound with sterile normal saline and surrounding skin with alcohol and transported immediately to Microbiology laboratory. Care was taken not to touch the wound edges inadvertently to avoid unnecessary skin contamination. A second sample was collected in all culture positives for staphylococci, for reproducibility of result, to confirm the presence of true infection and to rule out colonization and contamination.

\section{Direct smear study}

Direct smears were made from the first swab and stained with Grams stain. ${ }^{4}$ The smear was screened for the presence of inflammatory cells and the type of microbial flora.

\section{Culture}

The second swab was inoculated onto Mac Conkey agar and Blood agar. Inoculated plates were incubated aerobically at $37^{\circ} \mathrm{C}$ for complete 24 hours.

\section{Identification of Staphylococci ${ }^{5}$}

Cream to white, opaque Colonies on blood agar showing Gram positive cocci arranged in clusters in Grams stain smear were further subjected to additional tests such as catalase test [to differentiate from streptococci], Hugh leifson's oxidative fermentative test, susceptibility to Furazolidone $100 \mathrm{mg}$ disc and resistance to Bacitracin 0.04 units [to differentiate from micrococci], and coagulase test to identify coagulase positive and coagulase negative staphylococcus species.

\section{Antibiotic susceptibility testing}

The staphylococcal strains were subjected for antibiotic susceptibility testing by employing Kirby Bauer disc diffusion technique against cefoxitin $[30 \mu \mathrm{g}]$, penicillin[10 units], ampicillin[10 $[1 \mathrm{~g}]$, cefazolin $[30 \mu \mathrm{g}]$, ciprofloxacin $[5 \mu \mathrm{g}]$, gentamicin $[10 \mu \mathrm{g}]$, erythromycin $[15 \mu \mathrm{g}]$, 
clindamycin $[2 \mu \mathrm{g}]$ and linezolid $[30 \mu \mathrm{g}]$ discs. ${ }^{6}$ All the discs were procured commercially [Hi-media Laboratories limited].

The methicillin resistant staphylococcal strains were tested for vancomycin susceptibility by "Macrodilution broth susceptibility method". The MIC [Minimum Inhibitory Concentration] of the test strain was interpreted as the lowest concentration of vancomycin at which there was no visible staphylococcal growth judged by lack of turbidity and interpreted according to CLSI guidelines. ${ }^{7}$ ATCC S.aureus 25923 was used as control strain for the susceptibility testing.

All the statistical analysis was performed using the software SPSS for Windows (Statistical Presentation System Software, SPSS Inc, New York) version 22.

\section{RESULTS}

In the present study, 595 pus samples were collected from clinically suspected wound infection cases. Clinical diagnoses of the cases selected in the present study were diabetic foot, cellulitis, traumatic wound, osteomyelitis, nonhealing ulcer, post-operative wound infection, gangrene and burns.

Out of the 595 subjects, 425 [71.4\%] were male patients and 170 [28.6\%] were female patients. The male to female ratio in our present study was 2.5:1. The age and sex distribution of the samples is depicted in Table 1.

152 cases of diabetic foot and 122 cases of cellulitis were the predominant clinical cases in the present study. These were found more

Table 1. Age-Sex distribution

\begin{tabular}{cccccccc}
\hline \multirow{2}{*}{ S.No. } & \multirow{2}{*}{ Age/Sex } & \multicolumn{2}{c}{ Male } & \multicolumn{3}{c}{ Female } & \multicolumn{2}{c}{ Total } \\
& & No. & $\%$ & No. & $\%$ & No. & $\%$ \\
\hline \multirow{2}{*}{1} & $0-9$ & 18 & 4.2 & 9 & 5.3 & 27 & 4.5 \\
2 & $10-19$ & 34 & 8.0 & 9 & 5.3 & 43 & 7.2 \\
3 & $20-29$ & 55 & 12.9 & 22 & 12.9 & 77 & 12.9 \\
4 & $30-39$ & 72 & 16.9 & 14 & 8.2 & 86 & 14.5 \\
5 & $40-49$ & 64 & 15.1 & 36 & 21.2 & 100 & 16.8 \\
6 & $50-59$ & 80 & 18.8 & 33 & 19.4 & 113 & 19.0 \\
7 & $>60$ & 102 & 24.0 & 47 & 27.6 & 149 & 25.0 \\
& Total & 425 & 100 & 170 & 100 & 595 & 100 \\
\hline
\end{tabular}

Contingency Coefficient $=0.136 ; \mathrm{P}<0.080$ (NS)

among patients above 60 years. In this study it was observed that the Burns wound infection [M:F:: 1:1] and post operative wound infections[ M:F:: 1.5:1] were more common among females compared to other clinical conditions.

Out of 595 samples collected, 534 [89.7 \%] yielded growth of one or more bacterial species. 61 [10.3\%] samples did not yield growth of any bacterial species even after 48 hours of incubation. Out of these 61 samples, 19 samples showed presence of pus cells and bacteria in the direct smear examination. The result of correlation between direct smear study and culture isolates is shown in Table 2.

Among 534 culture positive samples, 152 yielded pure growth of only staphylococcal species, 88 showed mixed growth of staphylococci with other gram positive and gram negative bacteria and 294 samples yielded growth of bacterial species other than staphylococci.

Among the 216 samples in which only gram positive cocci was seen in the direct smear study 152 yielded pure growth of staphylococci, 23 samples showed mixed growth of staphylococci and other Gram positive bacteria, 30 samples yielded the growth of other gram positive cocci and in 11 samples there was no bacterial growth.

Out of 95 samples in which mixed bacterial flora of gram positive cocci and other bacteria was seen, 65 samples showed mixed growth of staphylococcal species and other bacteria. 27 yielded growth of bacteria other than staphylococci and 3 did not yield growth of any aerobic bacteria.

In the present study overall rate of wound infection based on direct microscopic examination 
Table 2. Association between Direct smear study and culture

\begin{tabular}{lllccccc}
\hline S. & Direct smear & & \multicolumn{5}{c}{ Culture isolates } \\
\cline { 3 - 7 } No. & study & & $\begin{array}{c}\text { Pure growth } \\
\text { of Staph }\end{array}$ & $\begin{array}{c}\text { staph+other } \\
\text { isolates }\end{array}$ & $\begin{array}{c}\text { Other } \\
\text { isolates }\end{array}$ & $\begin{array}{c}\text { No } \\
\text { growth }\end{array}$ & Total \\
\hline \multirow{2}{*}{1} & \multirow{2}{*}{ PC \& GPC } & No. & 152 & 23 & 30 & 11 & 216 \\
& & $\%$ & 70.4 & 10.6 & 13.9 & 5.1 & 100 \\
2 & PC, GNB \& GPC & No. & - & 65 & 27 & 3 & 95 \\
& & $\%$ & - & 68.4 & 28.4 & 3.2 & 100 \\
3 & PC \& GNB & No. & - & - & 237 & 5 & 242 \\
& & $\%$ & - & - & 97.9 & 2.1 & 100 \\
4 & Few PC, No org & No. & - & - & - & 32 & 32 \\
& & $\%$ & - & - & - & 100 & 100 \\
5 & No PC, No Org & No. & - & - & - & 10 & 10 \\
& \multirow{2}{*}{ Total } & $\%$ & - & 88 & 294 & 61 & 595 \\
& & No. & 152 & 14.8 & 49.4 & 10.3 & 100 \\
\hline
\end{tabular}

Contingency Coefficient $=0.799 ; \mathrm{P}<0.000$ (Highly Significant)

finding was $98.3 \%$. Staphylococcal wound infection rate was $40.3 \%$ and wound infections due to bacteria other than staphylococci were $49.4 \%$.

Among various clinical conditions, osteomyelitis [50.6\%] and burns [50\%] has yielded the highest staphylococcal growth and traumatic wounds have yielded the lowest [31.2\%] growth.

In the present study, among 240 staphylococcal isolates, 196 [81.7\%] were Staphylococcus aureus. The high rate of Staphylococcus aureus infection in the present study was observed among the cases of osteomyelitis [95\%] followed by gangrene [90\%].

Table 3. Distribution of Staphylococcus aureus among clinical samples

\begin{tabular}{llcc}
\hline \multirow{2}{*}{ S. } & \multirow{2}{*}{ Clinical diagnosis } & \multicolumn{2}{c}{ S. aureus } \\
No. & & No. & $\%$ \\
\hline & & 42 & 85.7 \\
2 & Diabetic foot & 48 & 81.4 \\
3 & Cellulitis & 18 & 62.1 \\
4 & Traumatic wound & 38 & 95.0 \\
5 & Osteomyelitis & 24 & 85.7 \\
6 & Non healing ulcer & 11 & 64.7 \\
7 & Gangrene & 9 & 90.0 \\
8 & Burns & 6 & 75.0 \\
& Total & 196 & 81.7 \\
\hline
\end{tabular}

Contingency coefficient $=0.257$;

$P$ value $=0.017$ (Highly significant)
The distribution of Staphylococcus aureus isolated from different clinical cases is shown in Table 3.

\section{Antibiotic susceptibility}

In our study, out of 196 Staphylococcus aureus, 58 [29.6\%] were methicillin resistant and 138 [70.4\%] were methicillin sensitive. Significant difference was observed in the susceptibility pattern of Methicillin Sensitive and Methicillin Resistant Staphylococcus aureus (Table 4)

Methicillin Resistant Staphylococcus aureus were completely resistant to both penicillin and ampicillin [100\%]. 57[98.3\%] MRSAs were resistant to cefazolin and gentamicin. 55[94.8\%] MRSA isolates were resistant to ciprofloxacin, 53[91.4\%] were resistant to erythromycin and 31 [53.5\%] were resistant to clindamycin. Thus in the present study, 31 strains of MRSA were found to be Multi Drug Resistant showing resistance to erythromycin, clindamycin, ciprofloxacin, gentamicin, cefazolin and penicillin group of drugs. Out of 138 methicillin sensitive S.aureus, 35 [25.4\%] strains were sensitive to penicillin and ampicillin, while 136[98.6 \%] were susceptible to cefazolin. The susceptibility rate of MSSA to gentamicin, ciprofloxacin, erythromycin and clindamycin was 92\%, 97.1\%, 94.9\% and $97.8 \%$ respectively. 3 MSSA strains showed inducible resistance to clindamycin. All staphylococci in our study were sensitive to linezolid and vancomycin. 
Table 4. Antibiogram of Staphylococcus aureus isolates

\begin{tabular}{|c|c|c|c|c|c|c|c|c|c|c|c|}
\hline \multirow{3}{*}{$\begin{array}{l}\text { S. } \\
\text { No. }\end{array}$} & \multirow[t]{3}{*}{ Drugs } & \multicolumn{4}{|c|}{ MRSA [n=58] } & \multicolumn{4}{|c|}{ MSSA [n=138] } & \multirow{3}{*}{$\mathrm{CC}$} & \multirow{3}{*}{$P$ value } \\
\hline & & \multicolumn{2}{|c|}{ Sensitive } & \multicolumn{2}{|c|}{ Resistant } & \multicolumn{2}{|c|}{ Sensitive } & \multicolumn{2}{|c|}{ Resistant } & & \\
\hline & & No. & $\%$ & No. & $\%$ & No. & $\%$ & No. & $\%$ & & \\
\hline 1 & Penicillin & 0 & - & 58 & 100 & 35 & 25.4 & 103 & 74.6 & 0.289 & .000 \\
\hline 2 & Ampicillin & 0 & - & 58 & 100 & 35 & 25.4 & 103 & 74.6 & 0.289 & .000 \\
\hline 3 & Cefazolin & 1 & 1.7 & 57 & 98.3 & 136 & 98.6 & 2 & 1.4 & 0.694 & .000 \\
\hline 4 & Gentamycin & 1 & 1.7 & 57 & 98.3 & 127 & 92 & 11 & 8 & 0.655 & .000 \\
\hline 5 & Ciprofloxacin & 3 & 5.2 & 55 & 94.8 & 134 & 97.1 & 4 & 2.9 & 0.675 & .000 \\
\hline 6 & Erythromycin & 5 & 8.6 & 53 & 91.4 & 131 & 94.9 & 7 & 5.1 & 0.65 & .000 \\
\hline 7 & Clindamycin & 27 & 46.6 & 31 & 53.5 & 135 & 97.8 & 3 & 2.2 & 0.532 & .000 \\
\hline 8 & Linezolid & 58 & 100 & 0 & - & 138 & 100 & 0 & - & - & - \\
\hline 9 & Vancomycin & 58 & 100 & 0 & - & 138 & 100 & 0 & - & - & - \\
\hline
\end{tabular}

Table 5. Comparison of Resistance pattern of MRSA isolates by various studies

\begin{tabular}{|c|c|c|c|c|c|c|c|c|c|}
\hline \multirow{2}{*}{$\begin{array}{l}\text { S. } \\
\text { No. }\end{array}$} & \multirow[t]{2}{*}{ Author } & \multicolumn{8}{|c|}{ Resistance pattern of MRSA isolates [\%] } \\
\hline & & $P$ & A & $\mathrm{Cz}$ & G & $\mathrm{Cf}$ & $\mathrm{E}$ & $\mathrm{Cd}$ & Va \\
\hline 1 & Uma Chaudhary et al ${ }^{11}$ & 100 & 100 & 96.8 & 38.2 & 5.7 & 42 & 6.3 & 0 \\
\hline 2 & Anvikar et $\mathrm{al}^{18}$ & 100 & 100 & - & 98.9 & - & 95.9 & - & - \\
\hline 3 & Udaya Shankar et al ${ }^{19}$ & - & - & - & - & 95.8 & - & - & - \\
\hline 4 & Hanumanthappa et a $\left.\right|^{20}$ & - & 100 & - & 81.39 & 65.11 & 93.02 & - & 0 \\
\hline 5 & Pulimood et al ${ }^{21}$ & - & - & - & 85.5 & 90 & - & - & 0 \\
\hline 6 & Kakru et al ${ }^{12}$ & 48 & 43 & 38 & 38 & 40 & 42 & - & 0 \\
\hline 7 & Anupurba et $a^{13}$ & 100 & 100 & 88.7 & 10.3 & 84.1 & - & - & 0 \\
\hline 8 & Majumder et al 22 & 94.1 & - & - & 70.3 & 22.8 & 33.9 & - & - \\
\hline 9 & Vidhani et al $^{14}$ & - & - & 79.5 & 79 & 33 & 22.3 & - & 0 \\
\hline 10 & Present study & 100 & 100 & 98.3 & 98.3 & 94.8 & 91.4 & 53.5 & 0 \\
\hline
\end{tabular}

\section{DISCUSSION}

The discovery and development of miracle antibiotics is undoubtedly one of the utmost advances of modern medicine. But, unfortunately, the emergence of multidrug resistant bacteria, is threatening the effectiveness of many of these antimicrobial agents.

When Penicillin was first introduced in early 1940s, almost all staphylococci were susceptible. By 1942, there were few isolated reports of penicillin resistance among S.aureus isolates, by 1950 s almost $50 \%$ of all strains were resistant to penicillin. In 1960, penicillinase resistant drugs such as methicillin, oxacillin, nafcillin etc., were introduced. By late 1970s Methicillin resistant strains of staphylococci emerged and they have become increasingly more established as nosocomial pathogens.
The Male to Female ratio in our study was 2.5:1. The increased rate of wound infections among males could be due to their outdoor occupation, more prone for injuries and infections occur due to exposure to contaminated environment. A similar observation has been made by Siddiqi et $a^{8}$ who have reported a male to female ratio of 2.6:1.

Out of 595 cases, 149 [25.1\%] were found in the sixth decade. Majority of these were cases of diabetic foot wounds and cellulitis. This is because of diminishing immunity as age advances and also the possibility of underlying hormonal abnormalities.

The direct gram stain smear study of the samples helps to confirm the presence of true infection, to identify the type and number of bacteria causing infection. It also gives a clue 
to the clinician to initiate an effective empirical antibiotic treatment pending culture report. Absence of inflammatory cells would suggest faulty collection of the sample or an indication of absence of pyogenic infection.

In the present study, Gram stained direct smear study revealed presence of infection in $98.3 \%$ of samples. $96.8 \%$ correlation between the gram stained smear finding and culture was observed in the present study. De et $\mathrm{al}^{9}$ also has observed a correlation rate of $87.3 \%$ which is comparable with that of the present study. Thus the observations of this study and that of other workers confirm that there is no replacement for a gram stained direct smear study in clinical microbiology.

In this study, $81.7 \%$ of the wound infections were caused by Staphylococcus aureus. Dang et al $^{10}$ have reported $79 \%$ infection with S.aureus.

The overall rate of MRSA infection in our study was $29.6 \%$. The MRSA infection rate is consistent with Uma Choudhary et $\mathrm{al}^{11}$ [26.8\%] and Kakru et $\mathrm{al}^{12}$ [33\%]. Higher MRSA infection rate is reported by Anupurba et $\mathrm{al}^{13}$ [52.5\%], Vidhani et $\mathrm{al}^{14,15}[51.6 \%$ and $42.02 \%]$ and Mohanty et al ${ }^{16}$ [38.56\%]. The higher rate in their studies has been attributed to fact that the study group was from a tertiary care multispecialty center with no admission policy and indiscriminate use of antibiotics.

The multidrug resistance of MRSA to a wide range of antibiotics is well known. The antibiotic susceptibility results showed that all MRSA isolates were significantly highly resistant to antibiotics than MSSA isolates $[P<0.00]$. The resistance pattern of MRSA to $\beta$ lactams like penicillin and ampicillin was $100 \%$ in our study. Similar findings were seen in the studies by Gupta et al, ${ }^{17}$ Uma choudhary et al, ${ }^{11}$ Anupurba et $\mathrm{al}^{13}$ and Anvikar et $\mathrm{al}^{18}$ (Table 5).

In the present study, $91.4 \%$ of MRSA isolates were resistant to erythromycin. Similar rate of resistance was observed in studies of Anvikar et $\mathrm{al}^{18}$ [95.9\%], Hanumanthappa et $\mathrm{al}^{20}$ [93.02\%] and Gupta et $\mathrm{al}^{17}$ [100\%]. 39.7\% [23 isolates] of MRSA isolates in present study were resistant to clindamycin. A consistent result was reported by Thouverez et al ${ }^{23}$ [30\%]. A low percentage of $6.3 \%$ was reported by Uma Choudhary et $\mathrm{a}^{11}$ and they have opined that clindamycin can be used as first line drug for treatment of MRSA infections.

Linezolid, the oxazolidinone has shown $100 \%$ efficacy against Staphylococcus aureus in the present study. Similar consistent activity of linezolid against MRSA has also been shown by Stevens et al. ${ }^{24}$ However, linezolid resistance in S.aureus has been reported by Tsiodras et al. ${ }^{25}$ As linezolid's antibacterial activity is comparable with that of vancomycin in the present study, linezolid can be used as another option to vancomycin in treating MRSA infections.

\section{CONCLUSION}

The observations of the present study conclude that staphylococcal infections are the most common cause of wound infections among hospitalized patients and continue to be a growing thorn in the Health care system. Despite the latest reports that Gram Negative bacteria have overtaken staphylococci as the leading cause of nosocomial infections, MRSA continues to be the major threat in the health care setting. The results of this study would not only contribute a great deal in the prevention of such infections but also help us in formulating an antibiotic policy for the treatment of Staphylococcal lesions in our hospital.

\section{REFERENCES}

1. Francis A. Waldvogel. Staphylococcus aureus (Including Staphylococcal Toxic Shock). In: Mandell GL, Bennett, Dolin R. Editors. Mandell, Douglas and Bennett's Principles and Practice of Infectious diseases. $5^{\text {th }}$ edn. Churchill Livingstone, 2000:2069-2092

2. Lyon BR, Skurray RA, Antimicrobial resistance of Staphylococcus aureus; genetic basis. Microbiology Review, 1987; 51:88-134.

3. Emori TG, Gaynes RP. An overview of nosocomial infections including the role of microbiology laboratory. Clinical Microbiology Review, 1993; 6:428.

4. Duguid JP. Staining methods. In:Collee JG, Fraser AG, Marmion BP, Simmons A, editors. Mackie and McCartney Practical medical microbiology. $14^{\text {th }}$ edn. Edinburg: Churchill Livingstone, 1996:796-800.

5. Baird. Staphylococcus: Cluster-forming grampositive cocci. In:Collee JG, Fraser AG, Marmion BP, Simmons A, editors. Mackie and McCartney Practical medical microbiology. $14^{\text {th }}$ edn. Edinburg: Churchill Livingstone, 1996:245-261. 
6. Bauer AW, Kirby WMM, Sherris JC, Turck M. Antibiotic susceptibility testing by a standardized single disc method. American Journal of Clinical Pathology, 1966; 45:493-496.

7. CLSI. Performance Standards for Antimicrobial Susceptibility Testing. $28^{\text {th }}$ ed. CLSI Supplement M100. Wayne, PA: Clinical and Laboratory Standards Institute; 2018.

8. Siddiqi F, Masood MB, Saba N, Samad A, Qayyum M, Qazilbash AA. Antibiogram sensitivity pattern of methicillin resistant Staphylococcus aureus isolates from pus samples. Pakistan J. Biological Sciences, 2002; 5(4):491-493.

9. De A, Varaiya A, Mathur M, Bhesania A. Bacteriological studies of gas gangrene and related infections. Ind. J. Med. Microbiol. 2003; 21(3):202-204.

10. Dang CN, Prasad YD, Boulton AJ, Jude EB. Methicillin resistant Staphylococcus aureus in the diabetic foot clinic: a worsening problem, 2003; 20(2):159-61.

11. Uma Chaudhary, Anupama. Prevalence of Methicillin resistance in Staphylococcus aureus. Ind. J. Med. Microbiol., 1999; 17(3):154-155.

12. Kakru DK, Assadullah S, Thoker MA, Wani T. Methicillin resistant Staphylococcus aureus: need for constant surveillance, stringent control and vigorous treatment measures. Indian J. Pathol. Microbiol., 2003; 46(1):121-123.

13. Anupurba S, Sen MR, Nath G, Sharma BM, Gulati AK, Mohapatra TM. Prevalence of methicillin resistant Staphylococcus aureus in a tertiary referral hospital in Eastern Uttar Pradesh. Ind. J. Med. Microbiol., 2003; 21(1):49-51.

14. Vidhani S, Mehndiratta PL, Mathur MD. Study of methicillin resistant S.aureus isolates from high risk patients. Ind. J. Med. Microbiol., 2001; 19(2):87-90.

15. Vidhani S, Mathur MD, Mehndiratta PL, Rizvi M. Methicillin resistant Staphylococcus aureus: the associated risk factors. Indian J. Pathol. Microbiol., 2003; 46(4):676-679.

16. Mohanty S, Arti K, Dhawan B, Das BK. Bacteriological and antimicrobial susceptibility profile of soft tissue infections from Northern India. Ind. J. Med. Sciences, 2004; 58(1):10-15.

17. Gupta N, Prakash SK, Malik VK, Mehndiratta PL, Mathur MD. Community acquired methicillin resistant Staphylococcus aureus: A new threat for hospital outbreaks? Ind. J. Pathol. Microbiol., 1999; 42(4):421-426.

18. Anvikar AR, Deshmukh AB, Karyakarte RP, Damle AS, Patwardhan NS, Malik AK et al. A one year prospective study of 3280 surgical wounds. Ind. J. Med. Microbiol., 1999; 17(3):129-132.

19. Udaya Shankar C, Harish BN, Umesh Kumar PM, Navaneeth BV. Prevalence of methicillin resistant Staphylococcus aureus in JIPMER hospital- A preliminary report. Ind. J. Med. Microbiology, 1997; 15(3):137-138.

20. Hanumanthappa AR, Chandrappa NR, Rajasekharappa MG. Prevalence of methicillin resistant Staphylococcus aureus in Karnataka. Ind J Pathol Microbiol 2003;46(1):129-132.

21. Pulimood TB, Lalitha MK, Jesudason MV, Pandian R, Selwyn J, John TJ. The spectrum of antimicrobial resistance among MRSA in a tertiary care center in India. Ind. J. Med. Research, 1996; 103:212-5.

22. Majumder D, Bordoloi JNS, Phukan AC, Mahanta J. Antimicrobial susceptibility pattern among methicillin resistant Staphylococcus isolates in Assam. Ind. J. Med. Microbiol., 2001; 19(3):138140.

23. Thouverez M, Muller A, Hocquet D, Talon D, Bertrand X. Relationship between molecular epidemiology and antibiotic susceptibility of methicillin resistant Staphylococcus aureus in a French teaching hospital. J. Clin. Microbiol., 2003; 52:801-6.

24. Stevens DL, Smith LG, Bruss JB. Randomized comparison of Linezolid versus oxacillindicloxacillin treatment of complicated skin and soft tissue infections. Antimicrob Agents Chemother, 2000; 43:3408-3413.

25. Tsiodras S, Gold HS, Sakoulas G. Linezolid resistance in a clinical isolate of Staphylococcus aureus. Lancet, 2001; 358:207-208. 